\title{
TABUNG HAJI MALAYSIA DALAM PERSPEKTIF EKONOMI
}

\author{
Nurhasanah* $^{*}$
}

\begin{abstract}
Malaysian Hajj Savings in Economic Perspective. The entity of Malay Muslims provide a heightened awareness to practice the teachings of Islam. Hajj as one of the fifth pillar of Islam is a priority agenda of empire since the early nineteenth century. The maintenance of Hajj initially became sultan competence as a symbol of Islam in the Malay leadership. This is because the Malay customs affairs and the affairs of the religion of Islam to be the competence of the king, not the government or the British Empire.
\end{abstract}

Keywords: hajj savings, economics, hajj

\begin{abstract}
Abstrak: Tabung Haji Malaysia dalam Perspektif Ekonomi. Entitas Islam di kalangan Muslim Melayu memberikan kesadaran yang tinggi untuk mengamalkan ajaran-ajaran Islam. Ibadah haji sebagai rukun Islam yang kelima menjadi prioritas agenda kerajaan sejak awal abad XIX. Pengurusan ibadah haji pada awalnya menjadi kompetensi sultan sebagai simbol kepemimpinan Islam di tanah Melayu karena urusan adat istiadat Melayu dan urusan agama Islam menjadi kompetensi raja, bukan pemerintah atau kerajaan Inggris.
\end{abstract}

Kata Kunci: tabungan haji, ekonomi, ibadah haji

Naskah diterima: 3 Desember 2010, dirvisi: 4 Mei 2011, disetujui: 12 Mei 2011.

${ }^{*}$ Sekolah Pascasarjana UIN Syarif Hidayatullah Jakarta. Jl. Ir. H. Juanda 95 Ciputat Jakarta. Email: nurzan_y@yahoo.co.id. 


\section{Pendahuluan}

Pada awalnya, penyelenggaraan haji di tanah Melayu menggunakan jasa para "Syekh Haji". Laksamana Hang Tuah dan rombongan misalnya, telah diberi tempat oleh Malek di Mekah ketika menunaikan ibadah haji dalam perjalanan menuju Turki. Di Medinah pun, Laksamana Hang Tuah dan rombongan juga tinggal dua belas hari di tempat Syekh Jamaluddin. ${ }^{1}$ Malek dan Syekh Jamaluddin ini berperan sebagai Syekh Haji. Lebih jelas lagi dalam Hikayat Hang Tuah yang dimuat dalam Tuhfah al-Nafis karya Raja Ali Haji dijelaskan bahwa Raja Ahmad (Ayah Raja Ali), Raja Ali Haji sendiri dan rombongan telah memilih Syekh Ahmad Mushaffa sebagai jasa Syekh Haji. Ketika Raja Ahmad, Raja Ali Haji dan rombongan sampai di Jedah pada tanggal 18 Sya'ban 1243 H (1827 M), mereka telah ditawarkan jasa Syekh Haji oleh Syekh Ismail, Syekh Daud, dan Syekh Ahmad Mushaffa. ${ }^{2}$

Pada tahun 1950-an, kegiatan Syekh Haji diketuai oleh Syekh Ibrahim alSagoff yang berpusat di Singapura dan dibantu oleh Syekh Ahmad al-Mansyor yang berpusat di Pulau Pinang. Mereka juga sebagai perwakilan Syekh Haji di Tanah Arab. Secara umum, sistem Syekh Haji berfungsi sebagai institusi yang menyelenggarakan urusan pemberangkatan calon haji ke tanah suci. Institusi Syekh Haji selain memberikan pelayanan kepada calon Jemaah haji di tanah air juga memberikan pelayanan di Tanah Suci. Adapun tugas Syekh Haji di Tanah Air adalah: Pertama, mengurus pendaftaran haji pejabat daerah. Keduaa, mengurus paspor haji, tiket kapal laut dan waktu pemberangkatan. Ketiga, mengantar Jemaah haji ke pusat haji Pulau Pinang atau ke Singapura. Keempat, memastikan transportasi kapal untuk Jemaah haji. Kelima, mengantar Jemaah haji ke kapal-kapal haji (di Singapura, Pulau Pinang, Pelabuhan Klang, Kuching, dan lain-lain. Keenam, mengantar barang-barang Jemaah haji ke kapal haji.

Untuk kelancaran proses ibadah haji di tanah suci, Syekh Haji di Tanah Suci juga memberikan pelayanan untuk menyukseskan rangkaian ibadah haji terutama kepada Jemaah haji dari Tanah Melayu. Dari catatan musim haji tahun 1949 tergambar bahwa, Syekh Haji di Tanah Suci menjalankan tugas sebagai berikut. Pertama, menyambut Jemaah haji yang tiba di Jedah; Kedua, mengurus barang-barang Jemaah haji; Ketiga, menyediakan tempat tinggal sementara di Jedah selama dua hari sebelum berangkat ke Mekah; Keempat, selama dua hari

${ }^{1}$ Jabatan Perdana Menteri, Sejarah Perkembangan Tabung Haji Malaysia 30 Tahun, (Kuala Lumpur: Utusan Printcorp, 1993), h. 43. Statemen ini telah dikutip dari Kassim Ahmad, ed. Hikayat Hangb Tuah, h. 472-478

${ }^{2}$ Raja Haji Ahmad dan Raja Ali Haji, Tuhfah al-Nafisî, Virginia Matheson, ed.; Siri Kajian Sastera Fajar Bakti, (Kuala Lumpur: Fajar Bakti Sdn. Bhd, 1982), h. 304. 
Syekh Haji juga mengurus pendaftaran calon Jemaah haji kepada kerajaan Arab Saudi. Kelima, menyediakan tempat penginapan di Mekah dan Medinah; Keenam, menyediakan transportasi ke Arafah, Muzdalifah dan Mina; Ketujuh, menjaga kebersihan kemah Jemaah haji; Kedelapan, mengurus visa keluar Jemaah haji setelah selesai melaksanakan ibadah haji dan ziarah ke Medinah.

Kerajaan-kerajaan negeri yang punya kompetensi terhadap persoalan agama Islam turut terlibat dalam proses penyelenggaraan ibadah haji. Tahun 1936, kerajaan Johor berdasarkan intruksi Dato Onn bin Jafar ketika itu menjadi anggota Majelis Mensyuarat Negeri Johor memberikan kemudahan dalam proses pelaksanaan ibadah haji. Dato Onn mengintruksikan supaya pegawai-pegawai Melayu Kerajaan negeri Johor diberikan kesempatan untuk cuti dan diberikan ongkos haji seperti kemudahan yang diberikan kerajaan negeri kepada pegawaipegawai Inggris untuk cuti dengan memberi ongkos pulang ke England. ${ }^{3}$

Sesuai dengan perkembangan eksistensi Syekh Haji, tahun 1976 terjadi perubahan dalam peraturan Syekh Haji terutama di Arab Saudi. Perubahan ini bertujuan untuk memantapkan sistem dengan menyalurkan peraturan atau cara administrasi yang sistematis. Untuk selanjutnya Syekh-syekh telah dibagi menjadi tujuh kumpulan, yaitu: Pertama, Iran, Turki, Eropa, dan orang-orang Amerika yang beragama Islam. Kedua, negara-negara Arab di Afrika Utara, Mesir, Sudan , Maghrib, Tunis. Ketiga, Amman, Teluk Yaman, Yamin Selatan, Amiriah Arab Bersatu, Bahrain Kuwait dan Qatar. Keempat, negara-negara Arab di Asia Barat, Syiria, Iraq, Jordan, Lebanon, dan Palestina. Kelima, Pakistan, India, Bangladesh, Sri Langka, Burma, dan Afghanistan. Keenam, Indonesia, Malaysia, Singapura, Thailand, Filipina, Brunai, Jepang, dan Cina. Ketujuh, Afrika Tengah, Afrika Selatan, dan Afrika Barat.

Adapun perubahan yang dimaksud adalah bahwa Syekh-Syekh Haji hanya dilantik oleh kerajaan Arab Saudi. Syekh-syekh Haji yang tidak dilantik di Arab Saudi tidak dibenarkan untuk bekerja di Arab Saudi, dan makanan dan minuman disediakan oleh pihak Syekh dengan tambahan bayaran 350 Riyal.

Dalam pola kerja Syekh Haji, Kerajaan Arab Saudi membuat aturan tentang penentuan kuota bagi setiap Syekh Haji supaya bisa memberikan pelayanan yang selaiknya kepada calon Jemaah haji. Untuk itu, Kerajaan Arab Saudi juga mengutus pegawai-pegawai dari Kementerian Haji ke setiap negara untuk memberikan penjelasan dan membuat kerja sama khusus dalam pelaksanaan haji. Setelah sistem Syekh Haji berjalan, namun masih ada beberapa persoalan yang timbul seperti ada di antara Syekh Haji yang tidak mahir dalam pengurusan Jemaah haji, sehingga menimbulkan kekeliruan pada Jemaah haji, karena di

\footnotetext{
${ }^{3}$ Jabatan Perdana Menteri, Sejarah Perkembangan, h. 46-47.
} 
antara mereka juga ada yang tidak kenal dengan Syekh hajinya, dan tidak jarang juga ada di antara Jemaah haji yang kehilangan barang, suami isteri yang terpisah dan sebagainya. ${ }^{4}$

Proses pelaksanaan ibadah haji di tanah Melayu terkait dengan kondisi negara yang dipimpin oleh kerajaan Inggris. Pemerintah Inggris melihat rangkaian pelaksanaan ibadah haji bagi Muslim Melayu punya implikasi politik dalam hal penentangan orang Melayu terhadap kekuasaan mereka. Pelaksanaan ibadah haji ini akan mempengaruhi pemikiran Jemaah haji yang pergi ke Mekah akibat islâh islâmiyyah yang sedang menjadi isu sentral. Orang melayu akhirnya akan memberontak terhadap penjajahan Inggris dan menginginkan kemerdekaan. Oleh karena itu, pemerintah Inggris tidak terlibat dalam persoalan pelaksanaan ibadah Haji. Selain sikap antipati Inggris terhadap prosesi ibadah Melayu Muslim ini, kompetensi pemerintahan Inggris di tanah Melayu dalam hal adat istiadat dan agama Islam telah terbatasi dengan adanya perjanjian Pankor T.M. 1874 dan beberapa perjanjian antara pihak Inggris dan raja-raja Melayu.

Pelaksanaan Ibadah haji terkait dengan prestasi kerja pemerintah dan hubungan luar negeri. Karena motif politik seperti itu, pemerintah Inggris mau tidak mau terlibat dalam kepengurusan penyelenggaraan ibadah haji. Tahun 1922, pemerintah Inggris mendirikan Komite Haji yang bertujuan mengendalikan hal-hal yang berkait dengan paspor haji dan pengembalian harta atau uang Jemaah haji yang meninggal. Pengarah Biro Perisik Politik Negeri-Negeri Selat dan Negeri-Negeri Melayu mengetuai komite ini dan Penguamcara Negara (Soliticator General) sebagai sekretaris dan dianggotai oleh Ketua Penasihat Islam di Singapura dan dua orang pemimpin Melayu di Negeri Melayu Bersekutu yaitu Raja di Hilir Perak dan Dato' Setia di Raja Selangor. Khusus untuk urusan luar negeri, Komite Haji meminta pejabat di London untuk melantik pegawai Melayu dengan seorang kerani untuk mengendalikan semua urusan Jemaah haji Melayu di Hijaz. ${ }^{5}$

Dengan upaya maksimal, Syekh Haji dan keikutsertaan pemerintah Inggris dalam urusan penyelenggaraan ibadah haji, masih terdapat beberapa keluhan. Berdasarkan catatan Dato' Haji Mohd. Salleh bin Haji Awang (MISBAHA) yang telah menunaikan ibadah haji tahun 1947, menggambarkan bahwa ada beberapa kendala yang menjadi keluhan bagi Jemaah haji dari Tanah melayu, seperti

${ }^{4}$ Dengan adanya beberapa masalah tersebut, upaya untuk ke arah perbaikan terus dilakukan. Maka, tahun 1982 Kerajaan Arab Saudi membuat perubahan terhadap sistem Syekh Haji yang sudah berlansung dengan sistem mu'assasah. Di Malaysia, sistem mu'assasah mulai berlaku pada tahun 1984.

${ }^{5}$ W.R. Raoff, The Conduct of The Haji From Malaya, h. 91. 
berdesak-desakan dalam kapal selama berlayar, penipuan dalam urusan masuk keluar barang-barang Jemaah di pelabuhan Jeddah, service yang tidak memuaskan selama di Jeddah, transportasi selama dalam rangkaian ibadah haji, dan persoalan ketersediaan air meskipun pada tahun 1947 merupakan awal terjadinya perubahan baru terhadap Jemaah haji di Tanah Melayu.

Tahun 1948, Menteri-Menteri Besar dan Raja-raja Melayu telah sepakat mendirikan Jawatankuasa Penasihat Haji. Eksistensi Jawatankuasa Penasihat Haji yang sekarang sudah diubah namanya dengan Majelis Penasihat Urusan Haji setelah dibubarkan antara tahun 1969-1973, dapat mengurangi kesulitan yang menjadi keluhan Jemaah haji ketika itu.

Tahun 1951, Kerajaan Inggris mengesahkan undang-undang yang berkaitan dengan urusan haji bagi orang-orang Islam di Tanah Melayu. Undang-undang ini dinamakan Ordinan Pengurusan Haji Orang-orang Islam 1951 (Federation of Malaya No. 56 of 1951 "The Muslim Pilgrims Ordinance 1951"). Pengesahan undang-undang ini bertujuan untuk memberikan cara yang baik dalam kepengurusan haji Muslim Melayu supaya keberangkatan ke tanah Arab dalam keadaan aman. Undang-undang ini meliputi persoalan-persoalan yang berhubungan dengan pengurusan perjalanan haji seperti mendapatkan tiket kapal, paspor haji, kesehatan, makanan dalam kapal dan di tanah suci serta transportasi selama dalam ibadah haji.

Pada kenyataannya, hampir 6000 orang Melaysia yang beragama Islam mayoritas penduduk kampung menunaikan ibadah haji ke Mekah. Menurut Tun Haji Abdul Razak pada waktu itu sebagai Timbalan Perdana Menteri, jumlah ini setiap tahun diperkirakan terus meningkat seiring dengan kemajuan ekonomi yang diraih melalui keberhasilan program pembangunan pemerintah.

Berdasarkan hasil kerja yang diajukan oleh Diraja Ungku Aziz, Kerajaan Persekutuan Tanah Melayu membentuk suatu Jawatankuasa Kebajikan Ekonomi Bakal-Bakal Haji. Jawatankuasa ditugaskan untuk mengkaji dan meneliti dan memberikaan laporan kepada kerajaan mengenai hal ihwal haji. Setelah hasil kajian dan penelitian dirumuskan, Jawatankuasa membuat laporan Kertas Putih/ 62 dan laporan tersebut disampaikan kepada kerajaan. Berdasarkan laporan Jawatankuasa, kerajaan mendirikan Perbadanan Wang Simpanan Bakal-Bakal Haji atau Pejabat Tabung Haji melalui Akta Parlimen bil. 34/62 yang disahkan tanggal 1 Nopember 1962 dan diresmikan September 1963.

Berdasarkan Undang-Undang tahun 1962 tentang pendirian Perbadanan Wang Simpanan Bakal-Bakal Haji (PWSBH), lembaga ini dibentuk di bawah pengawasan Tun Razak sebagai Menteri Pembangunan Negara dan Luar Bandar dan bertujuan memberi kemudahan bagi Jemaah haji Malaysia untuk menunai- 
kan ibadah haji dan menggalakkan deposit dalam rangka pembentukan modal untuk membeli saham-saham perniagaan dan terlibat lansung dalam pelbagai perusahaan dan perniagaan. Tahun pertama PWSBH Sampai tahun 1969, PWSBH telah berhasil menghimpun 40.000 sampai 1,500 orang deposan dengan deposit pada tahun 1969 sebanyak $\$ 12$ juta. \$ 8 juta dari deposit ini telah diinvestasikan dalam beberapa perniagaan. Dari investasi ini telah diperoleh $\$ 1,4$ juta keuntungan. Tahun 1966, 3\% dari keuntungan diberikan kepada deposan sebagai bonus sementara tahun 1967 meningkat menjadi 4\% dan tahun 1968 menigkat lagi menjadi $5 \%{ }^{6}$

Kompetensi PWSBH fokus kepada aktivitas menghimpun dana dan pemanfaatan dana. Sementara tugas pengawasan, keselamatan, persoalanpersoalan yang berhubungan dengan pelaksanaan ibadah haji menjadi wewenang Jabatan Urusan Haji (JUH). Meskipun JUH memberikan pelayanan yang maksimal kepada Jemaah haji seperti memberikan servis dengan mempersiapkan para koki dalam kapal haji di mana para koki telah dilatih oleh MARA sebelumnya. Namun secara ekonomi, dwi fungsi lembaga PWSBH dan JUH belum maksimal menghasilkan profit. Oleh karena itu, pemerintah memandang perlu untuk membentuk lembaga tunggal yang berkompeten untuk melaksanakan peran yang dilakukan PWSBH dan JUH dalam kaitannya dengan dana dan ibadah haji. Lembaga tunggal ini akan efektif dan efisien untuk meningkatkan profit. Berdasarkan kesepakatan sidang Dewan Rakyat dan Dewan Negara di Parlimen, Maka disahkan Undang-Undang Perbadanan-Perbadanan Wang Simanan Bakal-bakal Haji tahun 1962. Udang-undang ini diupayakan untuk mencakup beberapa sekshen Undang-Undang Bakal Haji tahun 1951 dan Undang-Undang Perbadanan Wang Simpanan Bakal Haji tahun 1962 yang dipandang masih relevan. Dengan Terbentuknya Undang-undang baru ini, maka pada tahun 1969, Perbadanan Wang Simpanan Bakal-Bakal Haji yang berpusat di Kuala Lumpur disatukan dengan Pejabat Urusan Haji yang telah didirikan tahun 1951 dan berpusat di Pulau Pinang. Gabungan dari kedua institusi ini melahirkan Lembaga Urusan dan Tabung Haji (LUTH) yang dibentuk tanggal 30 Agustus 1969 atau yang dikenal sekarang dengan Lembaga Tabung Haji (LTH) yang sudah diubah nama pada tahun 1995.

\section{Operasional Tabung Haji dalam Konteks Sosial, Politik, dan Ekonomi}

Penyelenggaraan ibadah haji di Malaysia terkait dengan kondisi sosial, politik, dan ekonomi. Ketika muncul ide untuk membentuk suatu lembaga yang

${ }^{6}$ Tun Haji Abdul Razak, Pernyata Resmi Perbahathan Parlimen Dewan Rakyat Yang Kedua Penggal Kelima, Jilid V No. 44, 13 Februari 1969 
berfungsi untuk menghimpun dana calon jemaah haji di era tahun 50-an, orang Melayu (Islam) berada dalam situasi dan kondisi sosial politik yang tidak menguntungkan. Upaya kekuasaan pemerintahan Inggris membangun kawasankawasan yang memberi manfaat kepada ekonominya melalui bisnis Cina seperti kawasan Barat semenanjung, mengakibatkan segala infrastruktur tertumpu di kawasan maraknya kegiatan ekonomi. Pemerintah Inggris membangun jalan raya dan transportasi kereta api yang memanjang dari Utara sampai Selatan Pantai Barat. ${ }^{7}$ Kebijakan pembangunan Inggris seperti ini membuat orang Melayu hidup di kawasan pinggiran atau di perkampungan khususnya Pantai Timur, dimana secara ekonomi, orang Melayu hidup sebagai petani tradisional yang masuk dalam kategori kebun kecil dan nelayan.

Berdasarkan hasil penelitian Ungku Aziz, pada tanggal 31 Desember 1957, di Tanah Melayu ada tiga juta orang Melayu dengan perkiraan 49\% dari jumlah penduduk di Tanah Melayu. 76\% di antara mereka bekerja sebagai petani dan nelayan dan 10\% bekerja sebagai guru, pegawai-pegawai kerajaan (pemerintah), pedagang, tuan tanah dimana rata-rata pendapatan mereka $\$ 200$ hingga $\$ 1.000$ sebulan. Kalau dibuat perbandingan, 3 dari 4 orang Melayu bekerja sebagai petani dan nelayan. 80\% dari orang Melayu tinggal di perkampungan. Dapat dipahami bahwa ekonomi Melayu adalah ekonomi kampung yang berdasarkan pertanian dan perikanan. ${ }^{8}$

Pertanian yang digeluti mayoritas orang Melayu adalah menanam padi. Tanah yang dimiliki petani Melayu untuk menanam padi relatif kecil, sewanya tinggi dan hasilnya kurang. Tidak jarang ditemukan mayoritas mereka selalu berutang dan harga padi ditentukan oleh para saudagar-saudagar yang memonopoli padi di pasaran. Rata-rata pendapatan mereka sebulan tidak kurang dari \$50 sebulan dan paling tinggi $\$ 100$ sebulan. Dengan pendapatan yang relatif kecil ini, orang Melayu mengalami kemiskinan sebagai problem dalam perekonomian. Menurut Ungku Aziz, ada tiga faktor utama yang menimbulkan kemiskinan di kalangan orang Melayu yaitu hasil usahanya kecil, mereka tertindas dan mereka terbiar. $^{9}$

Selain penghasilan orang Melayu yang relatif kecil sebagaimana yang telah dijelaskan, terjadi penindasan di kalangan mereka. Penindasan ini dilakukan dengan empat cara. Pertama, pekedai mengambil untung sangat berlebihan;

${ }^{7}$ Chamhuri Siwar, Surtahman Kastin Hassan, dkk, Ekonomi Malaysia, (Selangor: PEARSON MALAYSIA. SDN. BHD, 2005), Edisi VI, h. 9.

${ }^{8}$ UA.Aziz, Renchana-Renchana Ekonomi dan Kemiskinan, (Singapore: Pusaka Melayu, 1969), Cet. IV, h. 1, 3, dan 5 .

${ }^{9}$ U.A. Aziz, Renchana-Renchana Ekonomi, h. 7. 
kedua, mereka diberi utang oleh pemodal dengan bunga yang tinggi. Bunga yang sampai 100 hingga 200 persen pertahun; Ketiga, sewa tanah tinggi; Keempat penindasan gaji. ${ }^{10}$

Tidak hanya pada ketidakseimbangan aspek kemudahan infrastruktur, tapi juga dalam aspek yang lebih khusus yaitu pendapatan. Akibat kurangnya perhatian pemerintah Inggris terhadap sektor pertanian tradisional yang mayoritas diisi oleh orang Melayu, tidak mendapatkan kemudahan akses ekonomi untuk memajukan dan mengembangkan pertaniannya. Akibatnya sektor ini mengalami pertumbuhan yang rendah dan pendapatan juga rendah. Fenomena ini menyebabkan sektor ini gagal mewujudkan peluang kerja baru, sementara penduduk yang mayoritas Melayu bertambah. Selain semakin sempitnya lahan pertanian bagi orang Melayu, tingkat pengangguran orang Melayu juga meningkat drastis. Kemiskinan eksis mayoritas di kalangan Melayu.

Ketika ide pembentukan Malayan Union yang diformulasi oleh Inggris muncul, kelompok Melayu memperlihatkan perlawanan sebagai reaksi mereka dengan menghimpun kekuatan Melayu. Di bawah perisai partai UMNO yang berideologi Nasionalis Melayu, tampil mengadakan perlawanan terhadap pembentukan ide Malayan Union tersebut. Pada tanggal 1 Februari 1948, Kesatuan Tanah Melayu atau Malayan Union berhasil dihapuskan dan diganti dengan Persekutuan Tanah Melayu. Keberhasilan UMNO untuk menyingkirkan Malayan Union dan mewujudkan kembali kedaulatan Raja-raja Melayu serta kebumiputraan Melayu sembari terbentuknya Perlembagaan (konstitusi) Persekutuan Tanah Melayu 1948, memberikan kepercayaan diri kepada orang Melayu untuk kembali terlibat aktif dan konsentrasi di bidang ekonomi dengan kekuatan asset Melayu yang minim bila dibandingkan dengan etnis Cina.

Umat Islam Melayu mulai punya keberanian untuk menyampaikan aspirasinya kepada pemimpin-pemimpin Melayu. Pemimpin-pemimpin Islam di Persekutuan Tanah Melayu dan Singapura menyampaikan kecamannya terhadap persoalan pelaksanaan ibadah Haji. Persidangan Menteri-Menteri Besar juga telah membuat kesepakatan untuk menciptakan sistem pengelolaan haji. Berdasarkan reaksi-demi reaksi yang bersumber dari orang-orang Muslim Melayu ini, pada tahun 1949, pemerintahan Inggris membentuk sebuah Jawatankuasa (panitia) Penasihat untuk menasihati kerajaan tentang hal ihwal haji. ${ }^{11}$

Panitia ini terdiri atas satu orang ketua yang dicalonkan oleh persidangan Menteri-Menteri Besar, seorang wakil dari tiap-tiap negeri yang dilantik oleh

${ }^{10}$ U.A. Aziz, Renchana-Renchana Ekonomi, h. 8-10.

${ }^{11}$ Tuan Haji Mustapha Albakri bin Haji Hassan, Sir Kamil Mohamad Ariff binHadir Mastan, Report of the Pilgrimage Investigation Committee, (1948), h. 2. 
kerajaan-kerajaan negeri dan dua wakil resmi yang dilantik oleh Kerajaan Persekutuan Tanah Melayu dan Singapura. Pada tahun 1952, dilantik lagi seorang wakil yang mewakili Serawak, Borneo Utara dan Brunai. ${ }^{12}$

Tabung haji merupakan lembaga keuangan Islam pertama di mana pendiriannya terkait dengan rendahnya keterlibatan Muslim Malaysia dalam sistem perbankan negara ketika itu. Kondisi ini disebabkan oleh keyakinan Muslim bahwa Islam melarang perniagaan yang berunsur riba. Mereka berkeinginan untuk menunaikan ibadah haji mesti dari hasil usaha yang halal dan benar-benar suci dari riba. Masyarakat Muslim Malaysia melakukan simpanan atau tabungan yang bersifat primitif hanya dengan tujuan untuk menunaikan ibadah haji. Ada di antara mereka yang menyimpan uang di bawah bantal, atau dalam kaleng tabungan yang memiliki resiko kecurian, rusak dan sebagainya. Pada dasarnya simpanan untuk tujuan haji masyarakat Muslim ini bersifat idle.

Setelah melakukan penelitian tentang ekonomi luar Bandar pada tahun 50an, Ungku Aziz menemukan masyarakat Muslim menyimpan uang hanya untuk tujuan menunaikan ibadah haji. Tahun 1959, Ungku Aziz mengajukan momerandum kepada kerajaan (pemerintah) yang memandang perlu pendirian sebuah institusi atau lembaga keuangan untuk mengelola sumber-sumber tabung haji tersebut tanpa berdasarkan riba tapi dengan cara investasi-investasi yang tidak bertentangan dengan syariat Islam serta boleh memberi return yang pas kepada mereka. Menurut Ungku Aziz, kalau pemerintah menyetujui pendirian lembaga ini, maka bukan umat Islam saja yang diuntungkan, tapi juga untuk pembangunan negara.

Dalam momerendum tahun 1969, Ungku Aziz menyampaikan bahwa satusatunya motif utama orang Melayu menabung di Malaya adalah untuk menunaikan ibadah haji. Motif ini perlu dibantu dengan membuat institusi baru, di mana institusi ini tidak hanya untuk menolong mereka dengan mudah dan nyaman untuk menunaikan ibadah haji dengan waktu yang singkat dan dana yang efisien, tapi juga mampu menggalakkan ekonomi negara dan ekonomi luar bandar (kampung). ${ }^{13}$

\section{Investasi Dana Tabung Haji}

Investasi merupakan salah satu aktivitas Lembaga Tabung Haji selain pelayanan haji dan penghimpunan dana. Dana yang terkumpul dari penabung

\footnotetext{
${ }^{12}$ Tuan Haji Mustapha Albakri bin Haji Hassan, Sir Kamil Mohamad Ariff binHadir Mastan, Report of the Pilgrimage, h. 2.

${ }^{13}$ Terjemahan bebas penulis dari buku Ungku Abdul Aziz, Pilgrims Economy Improvement Plan, (Kuala Lumpur: T.P, 1959), h. 5.
} 
diinvestasikan untuk mendapatkan Return Lembaga Tabung Haji, selain memperoleh dana dari Simpanan Pendeposit dalam operasionalnya, juga bersumber dari pendapatan pelaburan (return) dan penerimaan pembayaran (sewaan misalnya). Dana-dana yang terkumpul ini dikelola—selain digunakan untuk biaya (cost)—untuk diinvestasikan. Lembaga Tabung Haji sebagai lembaga investasi telah menginvestasikan dananya dalam bentuk jangka pendek maupun di Pasar Uang Islam.

Sejak tahun 1969, Tabung Haji sudah berinvestasi di sektor perkebunan dengan projek pertama yaitu kebun kelapa sawit seluas 4.047 hektar di Keratong Pahang. Selanjutnya, secara bertahap, Tabung Haji mengembangkan projekprojek perkebunan lain sesuai dengan perkembangan nominal investasinya. ${ }^{14}$ Tiga tahun setelah berdirinya Lembaga Tabung Haji bertepatan dengan 28 Agustus 1972, dibentuk Perbadanan Ladang-Ladang Tabung Haji Sdn. Bhd (PLLTH). Melalui PLLTH, Lembaga Tabung Haji berinvestasi dengan melibatkan diri di bidang perkebunan. Perkebunan pertama yang dibuka adalah perkebunan Kota Bahagia Sungai Mengah di Keratong Pahang seluas 4.000 hektar. Dari sini, Lembaga Tabung Haji mengembangkan aktivitas perniagaannya dengan membeli tanah untuk perkebunan baru serta mengadakan kerja sama dengan agensi negeri dan perusahaan-perusahaan pribadi.

Dalam perkembangannya, Tabung Haji menghadapi kendala dalam hal memajukan perkebunan kelapa sawit. Karena sampai sekarang Tabung Haji punya ketergantungan kepada kerajaan-kerajaan negeri untuk mendapat tanah. Tahun 1986, kerajaan negeri tidak memberi izin kepada Tabung Haji secara langsung untuk mengambil tanah guna mengembangkan perkebunan, bahkan proposal-proposal Tabung Haji untuk meminta tanah ditolak. ${ }^{15}$ Sebagian besar tanah-tanah perkebunan diambil alih langsung oleh agensi-agensi kerajaan untuk diolah oleh perusahaan-perusahaan perkebunan yang dimiliki oleh agensi-agensi lain. Artinya, Tabung Haji bersaing dengan perusahaan-perusahaan perkebunan lain melalui program swastanisasi pemerintah Malaysia. Pihak-pihak swasta diberi kemudahan untuk membeli tanah dalam rangka memperluas perkebunannya, sementara Tabung Haji selain tidak agresif untuk membeli tanah seperti yang dilakukan pihak swasta, juga menghadapi kesulitan untuk mendapatkan tanah. ${ }^{16}$

Selain itu, seperti pihak lain di industri perkebunan mengalami ketergantungan tenaga kerja asing, Tabung Haji juga mengalami hal yang sama karena

\footnotetext{
${ }^{14}$ Jabatan Perdana Menteri, Sejarah Perkembangan, h. 325.

${ }^{15}$ Jabatan Perdana Menteri, Sejarah Perkembangan, h. 328.

${ }^{16}$ Jabatan Perdana Menteri, Sejarah Perkembangan, h. 328.
} 
rakyat Malaysia tidak tertarik untuk bekerja di perkebunan. Remaja-remaja Melayu yang berpendidikan lebih tertarik untuk bekerja di lembaga-lembaga pemerintah dan di perusahaan-perusahaan. Hal ini merupakan akibat dari program pendidikan dan urbanisasi yang diterapkan pemerintah. Masalah kekurangan tenaga kerja asing dalam industri perkebunan semakin meruncing, karena negara sedang menuju ke arah sebuah negara industri, maka perkebunan-perkebunan yang ada termasuk perkebunan Tabung Haji terpaksa bersaing dengan sektor pembangunan dan pertambangan untuk memperoleh tenaga kerja asing. ${ }^{17}$

Kondisi kekurangtenaga kerja asing, perkebunan-perkebunan mencoba menjalankan kerja dengan menggunakan mesin dan jentera (teknologi). Mayoritas perkebunan menggunakan jentera dan kapal terbang untuk pembajakan kebun, membasmi hama dan rumput. Di era ini, perkebunan menjadikan penggunaan tenaga kerja yang minimum sebagai solusi dimana sebelumnya seorang tenaga kerja dihitung bisa mengendalikan 15 hektar kelapa sawit, tapi sekarang seorang tenaga kerja bisa menjadi 20-25 hektar kebun kelapa sawit. Tentu saja hal ini menghabiskan biaya yang mahal. Biaya operasi meningkat juga turut menjadi kendala bagi perkebunan umum dan perkebunan Tabung Haji untuk memperoleh profit.

Pada tahun 1993, Tabung Haji telah memiliki kebun-kebun sawit di Pahang, Johor, Trengganu, Negeri Sembilan, dan Sabah seluas 23.067 hektar. 17.806 hektar dimiliki oleh Tabung Haji sendiri melalui anak-anak perusahaannya yaitu Perbadanan Ladang-Ladang Tabung Haji Sdn. Bhddan Ladang Tabung Haji Sabah Sdn. Bhd. Sedangkan sisanya seluas 5.261 hektar dimiliki melalui join venture dengan Pertumbuhan Peladang Negeri Terengganu dan Majelis Agama Islam Negeri Sembilan dan perusahaan-perusahaan lainnya. ${ }^{18}$

Seiring kemajuan dan perkembangan perkebunan Lembaga Tabung Haji, PLLTH diganti menjadi TH Plantations Sdh. Bhd (THPSB) pada tanggal 15 September 1997. 26 Mei 2005, THPSB terdaftar di Papan Utama Bursa Malaysia yang dikenal dengan TH Plantation Berhad (TH Plantations).

Selain investasi di sektor perkebunan, ada empat pendekatan yang digunakan dalam berinvestasi yaitu: Investasi ekuiti, instrumen pendapatan tetap, investasi hartanah, dan instrumen pasar uang. ${ }^{19}$ Dari data tahun 2007 dijelaskan bahwa investasi Lembaga Tabung Haji meliputi empat bidang yaitu ekuiti (modal), simpanan jangka pendek, investasi keuangan dan hartanah. Di antara

${ }^{17}$ Jabatan Perdana Menteri, Sejarah Perkembangan, h. 328-329.

${ }^{18}$ Jabatan Perdana Menteri, Sejarah Perkembangan, h. 325.

${ }^{19}$ Norhazimah Che Hassan, "Sitem Pengurusan Dana Secara Islam: Satu Penelitian", dalam Jurnal Pengurusan Jawhar, Vol. 1, No. 2, 2007, h. 85. 
empat bidang itu, ekuiti menempati posisi pos investasi terbesar bila dibandingkan dengan tiga bidang yang lain. Investasi ekuiti yang dilaksanakan oleh Lembaga Tabung Haji meliputi sektor riil dan lembaga-lembaga keuangan yang ada. Bahkan dua bidang investasi ini meliputi nasional dan go international.

Pada tanggal 31 Desember 2007, investasi di bidang ekuiti berjumlah hampir RM 7,6 Bilion dan mendominasi alokasi asset lebih kurang 44\%. Dengan jumlah investasi yang besar ini, Tabung Haji memegang saham dalam 161 buah perusahaan yang terdaftar, 25 perusahaan yang tidak terdaftar merupakan perusahaan subsidiary. Keuntungan dari penanaman saham dalam tahun 2007 juga telah menunjukkan peningkatan sebanyak RM 750 juta atau $155 \%$ dengan perolehan profit RM 1.233,1 pada tahun 2007 bila dibandingkan dengan profit RM 483,1 juta pada tahun 2006. Selain itu dengan investasi ekuiti, Tabung Haji telah memberikan pendapatan deviden dan profit pemilikan saham sejumlah RM 279,8 juta. Tentu saja pendapatan deviden dan profit saham ini merupakan penyumbang terbesar kepada jumlah keseluruhan pendapatan Tabung Haji tahun 2007 dengan masing-masing menyumbang sebanyak $66 \%$ dan $15 \% .{ }^{20}$

Pemerintah Malaysia di bawah Kementerian Perdagangan Antarbangsa dan Industri (MITI) menjadikan Lembaga Tabung Haji sebagai sumber ekuiti (modal) Bumiputera dalam perusahaan-perusahaan yang beroperasi di bursa Malaysia. Teknis pelaksanaan investasi yang ditawarkan oleh Penawaran Awl Awm (IPO) diterima melalui agensi kerajaan dan lembaga-lembaga keuangan. Tahun 2007, Lembaga Tabung Haji telah meluluskan 10 penawaran investasi IPO dari 25 penawaran IPO yang diajukan. Dengan jumlah investasi RM 151,5 juta. IPO yang yang telah dikucurkan dana investasi oleh Lembaga Tabung Haji terdiri atas tujuh perusahaan di papan utama yaitu sektor hartanah, Pembinan (bangunan), barangan pengguna, perladangan dan perniagaan (jasa) dan tiga perusahaan di papan kedua di sektor perindustrian dan barangan pengguna. ${ }^{21}$ Selain IPO, Lembaga Tabung Haji juga memberikan investasi saham terbitan khas pada enam perusahaan dengan investasi sejumlah RM 94,2 juta.

Adapun investasi Lembaga Tabung Haji dalam investasi keuangan yang lain mencakup investasi pembiayaan kepada perusahaan subsidiari, pembiayaan korporat, investasi bon Islam, dan unit tabungan Islamic Development Bank (IDB). Investasi dalam kategori ini mencapai sejumlah $6 \%$ pendapatan Lembaga Tabung Haji atau sebanyak RM 116,9 juta pada tahun 2007. Khusus pada investasi pada IDB Infrastructure Fund (IIF) dibuat di negara-negara anggota IDB bagi

\footnotetext{
${ }^{20}$ Annual Report (Laporan Tahunan) Lembaga Tabung Haji tahun 2007, h. 55-56.

${ }^{21}$ Annual Report Lembaga Tabung Haji, h. 56.
} 
projek-projek infrastruktur seperti tenaga air, utiliti, telekomunikasi, transportasi dan petrokimia. IIF dikelola oleh Enginaring Market Partnership (EMP) Bahrain. Investasi ini dibuat secara konsorsium dengan Lembaga Tabung Haji sebagai ketua konsorsium dan tiga anggota konsorsium sebagai anggota yaitu: Kumpulan Wang Simpanan Pekerja (KWSP), Lembaga Tabung Angkatan Tentara (LTAT) dan Kumpulan Wang Persaraan (KWP). Dengan Investasi di IIF ini, Lembaga Tabung Haji telah memberikan investasi sejumlah RM 38,5 juta dengan return investasi yang diterima sejumlah RM 24,5 juta.

Investasi Lembaga Tabung Haji dalam pembiayaan korporat adalah pada Projek Hospital Pusrawi. Projek ini terjalin dengan kerja sama antara Lembaga Tabung Haji dengan Majelis Agama Islam Wilayah Persekutuan (MAIWP) dengan nisbah 70:30 dan berdasarkan konsep Bina, Pajak dan Pindah (Build, Lease dan Transfer/ BLT). Projek yang bernilai RM 70,0 juta ini terdiri atas bangunan Hospital dan sebuah bangunan pendukung dengan perolehan return melalui pembayaran sewa pajak dari MAIWP selama tempo waktu 15 tahun.

Desember 2007, ivestasi Lembaga Tabung Haji di bidang Hartanah mencapai hampir RM 1,8 billion. Investasi ini meliputi pemilikan ruang pejabat, kompleks haji, kilang, perumahan dan rumah sakit. Pemilikan hartanah ini bukan hanya untuk Lembaga Tabung Haji saja, tapi juga ada yang disewakan sebagai sumber pendapatan. Pendapatan sewaan tahun 2007 meningkat sejumlah RM 9,3 juta berbanding dari tahun 2006 sejumlah RM 57,2 Juta dengan tahun 2007 sejumlah RM 66,5 juta. Pada tahun 2007 ada peningkatan pendapatan dari tahun 2006 sebanyak 16\%. Pendapatan sewaan ini menempati posisi sebagai penyumbang pendapatan Lembaga Tabung Haji sebanyak $4 \%$.

Berikut ini adalah kutipan rincian sewaan Lembaga Tabung Haji lima tahun terakhir berdasarkan jumlah kutipan sewaan dan jumlah ruang yang disewa.

Table 22

\begin{tabular}{cccccc}
\hline & 2003 & 2004 & 2005 & 2006 & 2007 \\
\hline Kutipan Sewa (RM juta) & 40 & 49 & 60 & 57 & 67 \\
\hline Rang disewa (\%) & 78 & 80 & 81 & 82 & 84 \\
\hline
\end{tabular}

Selain sewaan ini, Lembaga Tabung Haji juga memiliki tiga kompleks haji (hotel) yang berlokasi di Kelana Jaya, Selangor, Bayan Lepas, Pulau Pinang, dan Kota Kinabalu Sabah. Berikut ini adalah table tentang komplek haji berdasarkan jumlah kamar, jenis kamar, dan jumlah sewaan. 
Table 23

\begin{tabular}{lcccc}
\hline \multicolumn{1}{c}{ Jenis Kamar } & Standar & Superior & Deluxe Superior & Suite \\
\hline Jumlah Kamar & 87 & 20 & 14 & 14 \\
\hline Sewa Perkamar (RM) & 100 & 120 & 140 & 160 \\
\hline Paket 20 kamar dan lebih (RM) & & & & \\
\hline
\end{tabular}

\section{Penutup}

Dari pembahasan diatas dapat ditarik kesimpulan betapa koordinasi pemberangkatan haji sangatlah penting. Selain dibutuhkan keikutsertaan pemerintah secara langsung maupun tidak langsung. Sebagaimana halnya di negeri Malaysia, penanganan haji sudah dilakukan melalui Syekh Haji. Upaya yang dilakukan pun dilakukan dengan aktivitas pengadaan Tabung Haji. Sehingga calon Jemaah haji mendapat kemudahan dalam menjalankan ibadahnya. []

\section{Pustaka Acuan}

Annual Report (Laporan Tahunan) Lembaga Tabung Haji tahun 2007.

Chamhuri Siwar, Surtahman Kastin Hassan, dkk, Ekonomi Malaysia, Selangor: PEARSON MALAYSIA. SDN. BHD, 2005

Hassan, Norhazimah Che, "Sitem Pengurusan Dana Secara Islam: Satu Penelitian", Jurnal Pengurusan Jawhar, Vol.1 No. 2, 2007.

Jabatan Perdana Menteri, Sejarah Perkembangan Tabung Haji Malaysia 30 Tahun, Kuala Lumpur: Utusan Printcorp, 1993.

Raja Haji Ahmad dan Raja Ali Haji, Tuhfat al-Nafis, Virginia Matheson, ed; Siri Kajian Sastera Fajar Bakti , Kuala Lumpur : Fajar Bakti Sdn. Bhd, 1982.

Aziz, Ungku Abdul, Pilgrims Economy Improvement Plan, Kuala Lumpur: T.P, 1959.

Tuan Haji Mustapha Albakri bin Haji Hassan, Sir Kamil Mohamad Ariff binHadir Mastan, Report of the Pilgrimage Investigation Committee, 1948.

Tun Haji Abdul Razak, Pernyata Resmi Perbahathan Parlimen Dewan Rakyat Yang Kedua Penggal Kelima, Jilid V No. 44, 13 Februari 1969

UA. Aziz, Renchana-Renchana Ekonomi dan Kemiskinan, Singapore: Pusaka Melayu, 1969.

W.R. Raoff, The Conduct of The Haji From Malaya. 